\title{
The Impact of Talent Management on Employee Performance: The Mediating Role of Job Satisfaction of Generation Y Management Trainees in the Selected Public Banks in Sri Lanka
}

\author{
D. R. Wickramaaratchi \\ M Sc. Scholar \\ University of Sri Jayewardenepura \\ Ruwani.wickramaaratchi@gmail.com
}

\author{
G.D.N. Perera \\ Senior Lecturer \\ Faculty of Management Studies and Commerce, \\ University of Sri Jayewardenepura,Sri Lanka \\ dinokagnp@sjp.ac.lk
}




\section{Abstract}

Development of talent pool is believed to be a source of competitive advantage in today's dynamic business organisations whereas the middle role of talent management has been emerging with the recognition of significance with its impact on desirable employee level outcomes. The present study aims to fill up the existing research gap by examining the impact of talent management on employee performance in the context of selected public banks in Sri Lanka specifying the generation $Y$ management trainees. Also the study sheds light on the mediation role of job satisfaction with the talent management - employee performance link. Thus, the current study contributes to the literature in the field of talent management, employee performance and job satisfaction. The study was conducted on a sample of 180 generation $Y$ management trainees opted randomly from a sample frame of public banks. The data was mainly analysed using the analytical software SPSS version 23 that provided more meaning and validated results. Further Hayes' PROCESS Macro v3.3 with SPSS was used to measure the mediation effect. The findings reveal that talent management has a significant positive impact over employee performance and job satisfaction. Also, it reveals a significant positive relationship between employee performance and job satisfaction. Importantly, job satisfaction has bridged the gap of talent management employee performance link through mediation. According to the findings of the study, it is proposed that adopting talent management is worthwhile as it leads to build a satisfied young generation and improved performance at work.
\end{abstract}

Key Words: Employee Performance, Generation Y employees, Job Satisfaction, Sri Lankan Public Banks, Talent Management

\title{
Introduction
}

In the modern era as stated by Kaur (2013) the management of talent seems to be one of the crucial functions under the pillar of Human Resource Management (HRM) when playing a strategic role in organizations (cited in Chugh and Bhatnagar, 2011). Due to the aspirations of new generations (multiple career and multiple employer attitudes) mainly concerning on the generation $\mathrm{Y}$ employees, retaining such talents is becoming more difficult day by day. Hence investing on human capital is crucial to retain most appropriate talents of new generations while enhancing their performance. However, spending huge amounts of capital towards Human Resource (HR) is not always affordable due to the financial and other contemporary constraints (Innocenti, Pilati and Peluso, 2011). So the economic value of such organisational efforts should necessarily link with the individual Employee Performance (EP). 
Even though Talent Management (TM) acts as a trendy strategic role for modern organisations, yet very little research attention has been marked at TM impact on EP with the mediating role of Job Satisfaction (JS). Similar to any other organizations, banks have also been facing numerous challenges and changes through the history. In today's contemporary environment banks are concerning more on stability and survival in the industry by using new strategies of management aspects. Banks should try new marketing strategies and adopt with contemporary HR concerns (Dixit and Arrawatia, 2018).

Financial sector has faced many challenges over last decades which have caused high competition and low development. Hence today banks should pay more concern on JS and EP which lead to many other positive consequences and to avoid negative aspects. Concerning public banks in Sri Lanka, it can be observed that they are often faced with competition regarding rewards, remuneration, and selection processes than the private banks. Public banks should recruit employees on the merit of their qualifications and also provide rewards as that helps to gain extra talent from employees. Job rotations and promotions should be given by considering performance of employees. That will help employees to provide a better platform to perform well and encourage potential growth (Dixit and Arrawatia, 2018). So, TM strategies may help in developing employees' potentials and also retain current employees for a long time and lastly, to attract highly skilled workers for their organization (Bist and Shrivastava, 2013). It helps banks to win in today's competitive era and renew strategies for the challenges of tomorrow (Collings and Mellahi, 2010). Thus the study investigates the impact of TM on EP which is fundamental as a timely need for making significant decisions on enhancing performances in the banking industry.

Unfortunately, little attention has been given to studying TM practices and EP mediating with JS among bankers in Sri Lanka, even though a number have studied TM and EP among bankers in other developing countries. Hence it was concluded that there is a gap concerning TM, JS and EP in the Sri Lankan context regarding the generation $Y$ Management Trainee (MT)s in public banks. Accordingly, it is obvious that there is an empirical knowledge gap in the Sri Lankan context with regard to the TM, JS and EP. As there is limited research on the topic, factor-wise relationship remains unexplored. It is essential to identify the impact of TM on EP with the mediating role of JS of generation $Y$ MTs in public banks in Sri Lanka. To fill the existing gap, the research problem, addressed under this study is as: Does talent management impact on employee performance with the mediating role of job satisfaction of generation $Y$ management trainees in the selected public banks in Sri Lanka?

The objectives of the study are to examine the TM practices impact on EP of generation $Y$ management trainees; to examine the TM practices impact on JS of generation $Y$ management trainees; to inspect the JS impact on EP of generation $Y$ management trainees; and to find the mediating role of JS between TM and EP of generation $Y$ management trainees in the selected public banks in Sri Lanka. 


\section{Literature Review}

\section{Talent Management}

Despite the availability of many definitions for the term TM, Aston and Morton (2005) argue that there is no concise definition for the concept of TM. Studying the numerous definitions, it is evident that TM focuses on processes related to the life cycle of an employee such as recruitment, assignment, training and development, rewarding except for the resignation/termination. However, the critical point to note in these definitions is that even though these are common functions carried out by the HR department of an organization, in TM it is about the skilled and high potential individuals. Thus, it can be concluded that TM is not about managing the typical employees within the organization but about managing the highly talented and potential employees of the organization.

The above observations have been further confirmed by Iles, Chuai and Preece (2010) and Cappelli (2009), through dissimilar analysis of TM and HRM. There were three views regarding the definition of TM as follows:

1) TM is not fundamentally different from HRM: the fundamental functions of both HRM and TM are the same.

2) TM includes HRM with a specific emphasis: TM specifically focuses on HR processes related to talented people, accordingly, the focal point is "talent pool", both internally and externally of the organization.

3) TM concentrates on the proficiency development through managing the progression of talents within the corporation. This point elaborates that TM is not about developing a talent pool but paving way for the flow of talent.

Working definition of TM is based on Garrow and Hirsh (2008) for this study which involves TM of Y generation MTs in selected Sri Lankan public banks, and it was: doing things to attract best individuals, invest in their development, build their potential and retain individuals to exploit their strengths best towards the organisational success.

\section{Employee Performance}

Numerous scholars have defined EP in different ways and it most commonly refers to whether employees perform their jobs well. Griffin et al (2007) highlight JP as the degree of accomplishment of the task that makes up the employee's job. EP is a behaviour and it is something that employees do which is reflected in their actions (Campbell et al, 2009).

Working definition of EP of $\mathrm{Y}$ generation MTs in the selected public banks refers to the expertise of the worker executing dominant work duties, employee behaviours that support the related environment in which the core tasks and duties are performed, the capacity of the worker to adjust to modifications in work or climate and the harmful behaviour that negatively affects the well-being of the organization (Koopmans, 2014).

\section{Job Satisfaction}

JS has been associated with the fields of organisational behaviour, economics, management, psychology and sociology, leading to numerous definitions on the same (Rossi et al, 2010, cited in Buthelezi, 2014; Shodhganga, 2012). Skalli, Theodossiou, and Vasileiou (2008, cited in Buthelezi, 2014) and Kabir (2011) state that overall JS is a result of fractional satisfactions associated to numerous aspects of a person's job. Locke (2007) 
outlines JS as the "pleasurable emotional state resulting from the appraisal of one's job as achieving or facilitating the achievement of one's job value". JS could be simply described as when employees like what they do which is a result of the two emotional concepts; fondness of the employees' work and level of their passion with occupation (Bakotic and Babic, 2013, cited in Buthelezi, 2014). JS is a sense of comfort and progressive experience that an employee has linked to his or her job (Kularathna and Perera, 2016).

Working definition of JS of $\mathrm{Y}$ generation MTs in the selected public banks refers to employees' favourable intention towards the job and their true feelings towards the job, peers, superior, surroundings of job and entire things around the work.

\section{Generation $Y$}

Armour (2005) states that Generation $Y$ exists out of more than 70 million people, of which the first group is actively present in the workforce. According to Hewlett, Sherbin, and Sumberg (2009) Generation $\mathrm{Y}$ is double the size of Generation $\mathrm{X}$, revealing the impact this generation will have on the workforce. The range that Howe and Strauss (2009) had set for Generation Y from 1982 to 2002 has been widely accepted. Generation $\mathrm{Y}$ employees are to be influenced to become more satisfied with their jobs and more committed to their organizations affectively, continually, and normatively (Perera and Madagamage (2018).

\section{Conceptual Framework}

Reviewing the prevailing literature conceptual framework of the study was depicted in Figure 1. In the conceptual framework TM was considered as the independent Variable, EP as the dependent Variable and JS as the mediator Variable.

Figure 1: Conceptual Framework

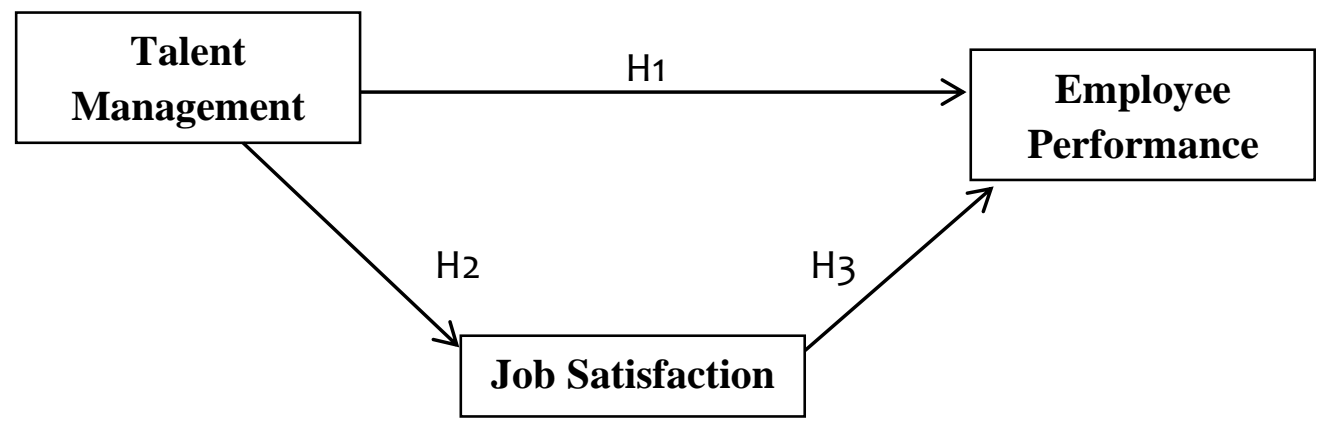

\section{Talent management and employee performance}

According to Fegley's (2006) reports on the Society for HRM indicates that TM model involves an integrated strategy or system that is designed to improve the processes of recruiting, developing and retaining people with the required skills and aptitude to meet current and future employee needs, which is essential to EP. TM is fundamental to any HR department to boost EP (Boxall and Purcell, 2008). As deeply explained in literature, properly handling talent is considered as one of the best options organizations can adopt 
to enhance performance and beat off competition (Mkamburi and Kumaara, 2017). According to Collings and Mellahi (2010), the concept of TM has a major impact on the workforce and if properly administered, it can make a difference on how employees perform. Hence, the first hypothesis is developed as follows:

Hypothesis $1\left(H_{1}\right)$ : Talent management has a positive impact on employee performance.

\section{Talent management and job satisfaction}

TM strategies are more useful for changing employee attitudes and satisfaction other than what is associated with enhanced organisational results (Dixit and Arrawatia, 2018). Hence TM is the substantial factor for the increase of employee's JS. TM dimensions such as Training and Development is used to boost employee motivation to higher level which directly affects the employees' behaviour and JS and also the career development opportunities which are used to lead to the improvement of JS (Latif and Sher, 2013). The sophisticated scope of the job which is modified through the TM has potential to lead to the improvement of JS (Dixit and Arrawatia, 2018). Further, they said mostly booming organizations have identified TM as a successful tool to increase JS of an employee; as a result the higher level of JS will create a motivated employee who in turn drives the organization to a better direction. Accordingly, the second hypothesis is formulated as follows:

Hypothesis $2\left(\mathrm{H}_{2}\right)$ : Talent management has a positive impact on job satisfaction.

\section{Job satisfaction and employee performance}

Sledge, Miles and Coppage (2008) investigated hotel employees' behaviour in Brazil and publicized that there is a positive relationship between JS and EP. Hellriegel, Solcum, and Woodman (2001) showed that JS impacts on effective EP. Perera (2014) highlighted that if an employee has high morale and enjoys his job, he will produce a huge commitment to work and will go that extra mile by enhancing the EP. Robbins (2005) emphasized that a person with a high level of JS, holds positive feelings about their job, whilst a person who is dissatisfied holds negative feelings about his|her job by suggesting a strong correlation between JS and EP. Perera (2019) discovered that JS positively influences EP among machine operators of Sri Lankan manufacturing firms. Hence, the third hypothesis can be developed as follows:

Hypothesis $3\left(\mathrm{H}_{3}\right)$ : Job satisfaction has a positive impact on employee performance.

\section{Job satisfaction's Impact on the relationship between talent management and employee performance}

The role of JS playing a mediation role in high performance work and EP has been studied by some researchers (Allen et al, 2003; Whitener, 2001; Rhoades, 2001), but conflicting results have been obtained between variables due to different HR practices (Whitener, 2001). Importantly, Luna-arocas and Morley (2018) stated in their study that TM practices affect both JS and EP, specifically there is a direct impact on JS while having an indirect impact on EP. Also efficient TM practises guide to enhance JS which boosts EP by enhancing their commitment towards the job (Tash, Ali, and Ahmadzadeh, 2016). Moreover, Luna-Arocas and Morley (2015) proved the positive relationship between 
talent mind set competency and JP through the mediating effect of JS. Accordingly, the fourth hypothesis can be formulated as follows:

Hypothesis $4\left(\mathrm{H}_{4}\right)$ : Job satisfaction mediates the relationship between talent management and employee performance.

\section{Methodology}

This study can be regarded as an analytical study and investigation type is co-relational. This study gathered data in the chosen public banks' normal surroundings without regulating the internal or external factors. This study explores the TM practices of the banks in order to find out its impact on EP and the mediating role of JS of different individuals (Management Trainee). The study unit is therefore individual. Data was gathered once in a specified period to answer the objective of the study (one month). This study is therefore a cross sectional study. The sample was drawn from 424 MTs of 2 public banks for the current study after contacting HR departments of the banks. Headcounts of MTs were selected for the study as all are young professionals who are representing the generation $Y$ with a high educational background. As they are required to possess at least a basic degree to enter the bank, they can be considered as talented employees. The sample chosen was two hundred and one (201) MTs belonging to generation $Y$ in public banks in Sri Lanka based on the Krejcie and Morgan (1970) Table. The most appropriate way of gathering data from respondents was discovered to be the electronic questionnaire technique (e-mails and what Sapp) using the Google form. The descriptive analysis was done with statistics related to demographic profile of the respondents of the study using the analytical tool of Statistical Package for Social Sciences (IBM-SPSS) version 23. The mediating effect was analysed using Hayes' PROCESS Macro v3.3 with SPSS.

\section{Measures}

First part of the questionnaire was used to gather data about demographic information of the MTs such as gender, age group, marital status, number of children, highest level of education and banking experience.

Second part of the questionnaire consisted of getting data about TM elements of the public banks. For this study purpose a scale of 31 items was developed referring to well accepted questions of other scholarly work which was used to measure TM practices by Nakhala (2013). The questionnaire focuses on the three dimensions of talent attraction, talent retention and talent development.

Third part of the questionnaire consisted of obtaining data about EP aspects of the MTs. Referring to other scholarly work, a scale of 45 items was developed for this purpose, consisting of four components namely task performance, contextual performance (both interpersonal and organisational), adaptive performance and counter-productive work behaviour (Koopmans, 2014).

Fourth part of the questionnaire is for getting data about JS aspects of the MTs.JS consists of five components namely satisfaction with the peers, satisfaction with the salary, satisfaction with the immediate supervisor, satisfaction with the nature of the job 
and satisfaction with the promotions (Siqueira, 2008; Luz and Oliver, 2018) as these factors are the most frequent factors of JS according to literature.

Respondents were requested to mark their best possible opinion or perception with the given question statements through the scale of 5 Likert points for all questions.

\section{Results}

The pilot study was conducted for 30 respondents from the sample. Cronbach's alpha was determined for each of the constructs as well as the dimensions to ensure the adequate reliability of the scale.The study marked high content validity as this study has hypothesized by basing on quality literature and specially conceptualized and operationalized based on literature (Kaushalya and Perera, 2018). Average Variance Extracted 0.5 or above ensures that the constructs are adequately convergent (Hair et al, 2014). Questionnaires were distributed among 201 MTs according to the sample size. 21 valid responses were not received, yielding a response rate of $90 \%$. The questionnaire was pretested and sent via e-mail mode for most of the respondents making all the filling rows as compulsory field $\left(^{*}\right)$ of which the movement to the next page was restricted without completing each of the items of the questionnaire. The current study included total of 180 responses out of which no missing value was reported.

\section{Demographic profile of the sample}

According to the information majority of the respondents are females which account for $62 \%$ of the total sample. As to age group, 93\% were fallen into age group of 1987 to 1993 . According to the marital status $66 \%$ were unmarried and this might be due to the reason that the majority of males do not get married in mid-twenties. Similarly, majority of MTs (86\%) do not have children as the majority were unmarried. Regarding the educational level, $68 \%$ of respondents have Bachelors while $12 \%$ have professional qualifications which are compulsory entry level qualifications to apply for the post of MTs. The remainder had dual degree and masters cumulatively $20 \%$. Out of 180 MTs in the sample more than half (61\%) MTs were from Bank 1 while 39\% represent from bank 2. Considering the district in which MTs are working, almost 19 districts were represented for the study by covering the whole country. Regarding banking experience $77 \%$ were having one to two years of experience as majority were born in $80 \mathrm{~s}$ and $90 \mathrm{~s}$.

\section{Testing Hypotheses}

\section{$\mathrm{H}_{1}$ : Talent Management has a Positive Impact on Employee Performance.}

Analysis of correlation was used to determine the association between the variables, TM and EP.

Table 1: Correlation Analysis H1

\begin{tabular}{|ll|r|r|}
\hline & & \multicolumn{1}{|c|}{ TM } & \multicolumn{1}{|c|}{ EP } \\
\hline TM & Pearson Correlation & 1 & $.402^{* *}$ \\
& Sig. (2-tailed) & & .000 \\
\hline EP & Pearson Correlation & $.402^{* *}$ & 1 \\
& Sig. (2-tailed) & .000 & 180 \\
\hline \multirow{2}{*}{ **. Correlation is significant at the 0.01 level (2-tailed). }
\end{tabular}


The observed Pearson Correlation Coefficient is 0.402 , according to Table 1, implying that a positive relationship occurs between the TM and the EP. Additionally regression analysis was used to find out the impact of the independent variable on the dependent variable.

Table 2: Model Summary H1

\begin{tabular}{|l|c|r|r|r|r|r|r|}
\hline $\begin{array}{l}\text { Mode } \\
\mathrm{I}\end{array}$ & $\mathrm{R}$ & R Square & $\begin{array}{l}\text { Adjusted } \\
\text { R Square }\end{array}$ & $\begin{array}{r}\text { Std. Error of } \\
\text { the Estimate }\end{array}$ & Constant & b value & \multicolumn{1}{c|}{ Sig. } \\
\hline 1 & $.402^{\mathrm{a}}$ & .161 & .151 & .44429 & 2.589 & 0.402 & .000 \\
\hline
\end{tabular}

a. Predictors: (Constant): TM

b. Dependent Variable: EP

The outcomes show (Table 2 ) that the multiple regression coefficients ( $R$ ) of the TM related independent variables and EP was 0.402 and the $R$ Square was 0.161 . It indicates that about 16.1 percent of the variance ( $R$ Square) in the EP is explicated by TM. Accordingly, regression equation of EP of MTs is: $E P=2.589+0.402(T M)$. The $p$-value is below 0.05 which ensures that TM can be used to forecast EP (refer to Table 2).

\section{$\mathrm{H}_{2}$ : Talent Management has a Positive Impact on Job Satisfaction.}

Analysis of correlation was used to assess the relationship between TM variable and JS variable of the study.

Table 3: Correlations $\mathrm{H} 2$

\begin{tabular}{|ll|r|r|}
\hline & & \multicolumn{1}{|c|}{ TM } & \multicolumn{1}{|c|}{ JS } \\
\hline TM & Pearson Correlation & 1 & $.753^{* *}$ \\
& Sig. (2-tailed) & & .000 \\
\hline JS & Pearson Correlation & $.753^{* *}$ & 1 \\
& Sig. (2-tailed) & .000 & \\
**. Correlation is significant at the 0.01 level (2-tailed).
\end{tabular}

Based on Pearson movement correlation findings (Table 3) for the two variables the coefficient is 0.753 which discovered that there is a positive connection between TM and JS among MTs in selected public banks in Sri Lanka. Also, a significant relationship between these two variables can be statistically claimed: TM and JS. Additionally regression analysis was also conducted to assess the impact of TM on JS.

Table 4: Model Summary $\mathrm{H}_{2}$

\begin{tabular}{|l|c|r|r|r|r|r|c|}
\hline Model & $\mathrm{R}$ & R Square & $\begin{array}{c}\text { Adjusted R } \\
\text { Square }\end{array}$ & $\begin{array}{c}\text { Std. Error of } \\
\text { the Estimate }\end{array}$ & Constant & b value & Sig. \\
\hline 1 & $.753^{\mathrm{a}}$ & .567 & .562 & .39699 & 0.193 & 0.753 & $.000^{\mathrm{b}}$ \\
\hline
\end{tabular}

a. Predictors: (Constant), TM b. Dependent Variable: JS

The results show (Table 4 ) that the multiple regression coefficient ( $R$ ) of the TM and the JS was 0.753 and the R Square was 0.567 . It indicates that about 56.7 percent of the variance ( $R$ Square) in the JS is explicated by TM. Accordingly regression equation of JS 
of MTs is: JS=0.193+0.753 (TM). The $p$-value is below 0.05 . This value ensures that TM can be used to forecast JS (refer Table 4).

\section{$\mathrm{H}_{3}$ : Job Satisfaction has a Positive Impact on Employee Performance.}

The relationship between JS and EP variables of the study was determined through the analysis of correlation.

Table 5: Correlations $\mathrm{H}_{3}$

\begin{tabular}{|ll|r|r|}
\hline & & \multicolumn{1}{|c|}{ JS } & \multicolumn{1}{|c|}{ EP } \\
\hline JS & Pearson Correlation & 1 & $.237^{*}$ \\
& Sig. (2-tailed) & & .034 \\
\hline EP & Pearson Correlation & $.237^{*}$ & 1 \\
& Sig. (2-tailed) & .034 & \\
\hline
\end{tabular}

*. Correlation is significant at the 0.05 level (2-tailed).

Based on the findings the Pearson correlation coefficient (Table 5) for the relationship between the two variables is 0.237 which revealed that there is a positive connection between JS and EP among MTs in selected public banks in Sri Lanka. Also, a significant relationship between these two variables can be statistically claimed owing to the fact that the $P$ value is less than .05 . Additionally regression analysis was also conducted to assess the impact of variable JS on variable EP.

Table 6: Model Summary $\mathrm{H}_{3}$

\begin{tabular}{|l|c|r|r|r|r|r|c|}
\hline $\begin{array}{l}\text { Mode } \\
\mathrm{I}\end{array}$ & $\mathrm{R}$ & $\mathrm{R}$ Square & $\begin{array}{c}\text { Adjusted R } \\
\text { Square }\end{array}$ & $\begin{array}{c}\text { Std. Error of } \\
\text { the Estimate }\end{array}$ & Constant & $\mathrm{b}$ value & \multicolumn{1}{c|}{ Sig. } \\
\hline 1 & $.237^{\mathrm{a}}$ & .056 & .044 & .47129 & 3.243 & 0.237 & $.034^{\mathrm{b}}$ \\
\hline
\end{tabular}

a. Predictors: (Constant), JS b. Dependent Variable: EP

The output shows (Table 6 ) that the multiple regression coefficient ( $R$ ) showing the impact of JS on EP was 0.237 and the R Square was 0.056 . It indicates that about 5.6 percent of the variance ( $R$ Square) in the EP is explained by JS. Accordingly regression equation of JS of MTs is: $E P=3.243+0.237$ (JS). The $p$-value is below 0.05 suggesting that JS can be a predictor of EP (refer to Table 6).

\section{$\mathrm{H}_{4}$ : Job Satisfaction Mediates the Relationship between Talent Management and Employee Performance.}

Hayes' PROCESS Macro v3.3 with SPSS was used to perform mediation analysis of JS between TM and EP at 95 confidence level. Table 7 produces the results of mediation test. 
Table 7: Testing for Mediation Effect $\mathrm{H}_{4}$

\begin{tabular}{|c|c|c|c|c|}
\hline & Direct Effect & Indirect Effect & $\begin{array}{c}\text { Total } \\
\text { Effect }\end{array}$ & $\begin{array}{c}\text { Mediation } \\
\text { Effect }\end{array}$ \\
\hline Path & $\mathrm{TM} \rightarrow \mathrm{EP}$ & $\mathrm{TM} \rightarrow \mathrm{JS} \rightarrow \mathrm{EP}$ & & \multirow{4}{*}{$\begin{array}{l}\text { Job } \\
\text { satisfaction is } \\
\text { acting as a } \\
\text { mediator on } \\
\text { TM and EP }\end{array}$} \\
\hline Co-efficient & 0.239 & 0.140 & 0.379 & \\
\hline P-Value * & 0.0248 & 0.0037 & 0.0002 & \\
\hline Accept or Reject & Accept & Accept & Accept & \\
\hline
\end{tabular}

* Significant at 0.05 level

In relation to the results of Table 7, mediation exists between TM and EP with a total effect $0.379, p<0.05$. Both direct and indirect paths were significant, resulting in mediation between the two constructs. Refer to Figure 2 to have a graphical idea.

Figure 2: Mediation Effect of Job Satisfaction $\mathrm{H}_{4}$

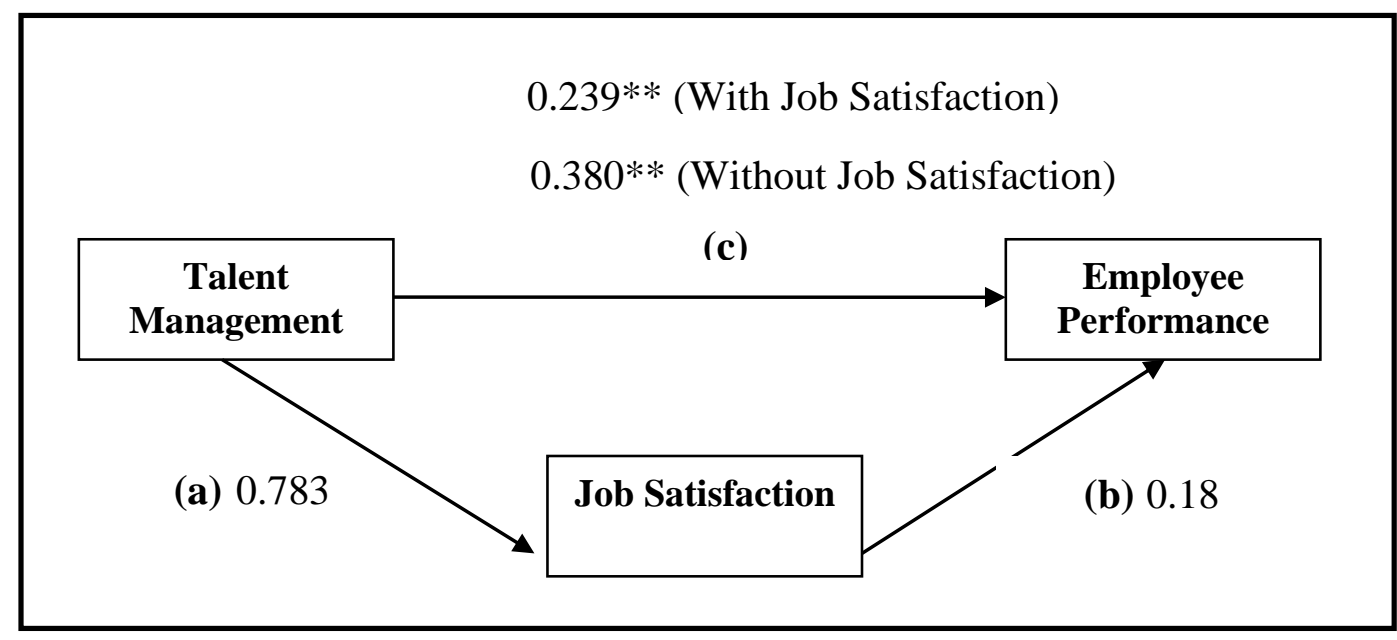

** Significant at 0.05 level

\section{Discussion}

The current study revealed a positive impact of TM on EP and this finding is consistent with empirical studies of Mangusho, Murei and Nelima (2015); Mkamburi and Kumaara (2017); Chegeni and Salavati (2016); Mwangi et al (2014); Mary, Eniynna and Ezinne (2015); Mensah (2015); Mensah, Bawole, and Wedchayanon (2016); Gelens et al (2014); LunaArocas and Morley (2015). Further this relationship is consistent with an empirical study carried out in Asian banking sector by Sadri et al (2015).

Pearson Correlation Coefficient is suggesting that there is a positive relationship between the TM and JS. Additionally regression analysis was used to confirm the positive impact of TM on JS of MTs in public banks. The positive relationship between TM and JS 
is consistent with empirical studies of Tash, Ali, and Ahmadzadeh (2016); Luna-Arocas and Morley (2015); Latif and Sher (2013). Further this finding is similar to the finding of the study conducted in Asian banking sector by Dixit and Arrawatia (2018). Thus the finding of this study will be added to the above empirical studies which have substantiated a positive linkage between TM and JS in the banking sector.

With reference to the correlation coefficient value, there is a significant positive relationship between JS and EP. Also there is a positive impact of JS on EP among MTs in the Sri Lankan public banking sector according to the regression analysis. According to Robbins (2005), if employee has high morale and enjoys his job, he will produce a huge commitment to work and go that extra mile by enhancing EP. The findings are steady with prior studies (Perera, 2014) and this means that employees were satisfied with their jobs and consequently increased their performance levels.

There is mediation played by JS on TM-EP relationship with a coefficient of 0.379 for the total effect (direct path + indirect path). Hence the context was mediated significantly by JS. Further the choosing of JS as a mediator is consistent with the empirical studies in similar context such as Tash, Ali, and Ahmadzadeh (2016); Luna-Arocas and Morley (2015). Further the mediating effect is similar to the studies conducted in the Asian banking sector such as Dixit and Arrawatia (2018).

In view of the current study, the MTs of the public sector banks were chosen because they were considered to be young and talented. Thus the results of the study showed that such talented young professionals feel their banks as investing time and effort on them in terms of recruitment and selection, use of branding, career advancement, compensation management, providing challenging task and supportive culture and ensuring work family balance. It was found that they responded with increased motivation, sense of JS ultimately leading to improve their performance level and potential.

\section{Conclusion}

By considering the above context, it can be concluded that the results of the present study have vital implications for managers and banking organisations implementing or intending to invest on TM practices. The findings of the study strengthen the view of investing human capital which would lead for better performance if the organisations invest in TM practices. Due to the service nature of the banking sector, the customers are highly connected to the employees in banks in fulfilling their financial needs, thus concern on skilled staff is a must to acquire or secure the competitive advance that derives from the strength of employees. The result of the study indicates a strong relationship between TM and EP; it justifies the confidence in investing on talent as well as provides inducement for those who wish to invest for better performance.

Further, the indication of TM positively relates to JS, which can be boosted in such investment on the mentioned initiatives. Hence a satisfied employee will produce more output for the organisation. Further the study emphasises that banks should re-think of investing, by taking into consideration the economic value of such practices. The above practices are in line with the enhancing ability, satisfaction and opportunity to learn and 
grow within the bank, which ultimately result in improved EP. Thus such effects would result in developing sustainable competitive advantage through a satisfied and engaged, young talented workforce with the effects of TM practices.

\section{References}

Allen, D.G., Shore, L.M. and Griffeth, R.W. (2003), The role of perceived organizational support and supportive human resource practices in the turnover process, Journal of Management, Vol. 29, No. 3, pp. 99-118.

Armour, S. (2005), Generation Y: They've arrived at work with a new attitude, USA.

Aston, C. and Morton, L. (2005), Managing Talent for competitive advantage, Strategic HR Review, Vol. 4, No. 5, pp. 28-31.

Bist, D.S.S. and Shrivastava, N. (2013), Talent Management Scenario in the Banking Industry, Indian Journal of Research, Vol. 2, No. 4.

Boxall, P. and Purcell, J. (2008), Strategy and Human Resource Management, Basingsoke: Palgrave Macmillan.

Buthelezi, M. (2014), Researching Job Satisfaction of Employees in Durban, Unpuplished Master thesis, Graduate School of Business and Leadership, College of Law and Management Studies: University of Kwazulu-Natal.

Campbell, J.P., McCloy, R.A., Oppler, S.H. and Sager C.E. (2009), A theory of performance in Organizations, San Francisco: Jossey-Bass.

Cappelli, P. (2009), Talent management for the 21st century, Harvard Business Review, Vol. 86, No. 3, pp. 74-81.

Chegeni, B. and Salavati, A. (2016), Investigating the Relationship between Employee's Talent Management and Job Performance in Agricultural Jihad Organization of Kurdistan (Three Headquarters), International Journal of Humanities and Cultural Studies, online, pp. 1336-1351, viewed 30 March 2019, <http://www.ijhcs.com/index.php/ijhcs/index>.

Chugh, S. and Bhatnagar, J. (2011), Talent management as high performance work practice: emerging strategic HRM dimension, Management and Labor Studies, Vol. 31, No. 3, pp. 228-253.

Collings, D.G. and Mellahi, K. (2010), The barriers to effective global talent management: The example of corporate élites in MNEs, Journal of World Business, Vol. 45, No. 2, pp. 143-149.

Dixit, S. and Arrawatia, M. (2018), The Impact of Talent Management on Job Satisfaction and Employee Performance in Public Sector Banks of Rajasthan, International Journal of Creative Research Thoughts, Vol. 6, No. 1, pp. 425-435, viewed 10 March 2019, <http://www.ijcrt.org>.

Fegley, S. (2006), Talent management survey report-2006, SHRM Research Department: USA.

Garrow, V. and Hirsch, W. (2008), Talent Management: Issues of focus and fit, Public Personal Management, Vol. 37, No. 4, pp. 389-402.

Gelens, J., Dries, N., Hofmans, J. and Pepermans, R. (2014), The role of perceived organizational justice in shaping the outcomes of talent management: a research agenda, Human Resource Management Review, Vol. 23, No. 4, pp. 341-353.

Griffin, M.A., Neal, A. and Parker, S.K. (2007), A new model of work role performance: positive behavior in uncertain and interdependent contexts, Academy of Management Journal, Vol. 50, pp. 327-347. 
Hair, J.F., Black, W.C., Babin, B.J. and Anderson, R.E. (2014), Multivariate Data Analysis, Prentice Hall, Upper Saddle River: New Jersey.

Hellriegel, Slocum, and Woodman, (2001), Organization Behavior, Ohio: South-Western College Publishing.

Hewlett, S.A., Sherbin, L. and Sumberg, K. (2009), How Gen Y and Boomers will reshape your agenda, Harvard Business Review, Vol. 87, pp. 71-76.

Howe, N. and Strauss, W. (2009), Millennials rising: The next great generation, Random House Digital: Inc.

Iles, P., Chuai, X. and Preece, D. (2010), Talent management fashion in HRD: Toward a research agenda, Journal of Human Resource Development International, Vol. 10, pp. 125-145

Innocenti, L., Pilati, M. and Peluso, A.M. (2011), Trust as a moderator in the relationship between HRM practices and employee performance, Human Resource Management Journal, Vol. 21, No. 3, pp. 303-317.

Kabir, M.M.N. (2011), Factors Affecting Employee Job Satisfaction of Pharmaceutical Sector, Australian Journal of Business and Management Research, Vol. 1, No. 9, pp. 113-123.

Kaur, R. (2013), Empirical Study of Talent Management Program and Its Impact on the Employee's Retainment and Performance in Indian Supermarket Big Bazaar, Human Resource Management Research, Vol. 3, No. 3, pp. 61-70.

Kaushalya, R.K.N. and Perera, G.D.N(2018), The Impact of Work Life Balance on Employee Turnover Intention in Selected Private Banks in Colombo District, Sri Lanka, Human Resource Management Journal, 2018, Vol. 6, No. 1,pp.25-33.

Koopmans, L. (2014), Measuring Individual Work Performance, The Netherlands: VU University, Medical Center.

Krejcie, R.V. and Morgan, D.W. (1970), Determining sample size for research activities. Educational and Psychological Measurement, Vol. 30, pp. 607-610.

Kularathna, W.K.H.U. and Perera, G.D.N. (2016). The Impact of Safety and Health on Job Satisfaction in Selected Branches of Utility Service Supply Organization in Western Province North in Sri Lanka, 3rd International HRM Conference, Vol.3, No.1, pp.137147.

Latif, K.I. and Sher, M. (2013), Perceived Organisational Support, Pay Satisfaction, and Supervisor Satisfaction Impact on Career Satisfaction, Abasyn University Journal of Social Sciences, Vol. 5, No. 1, pp. 32-48.

Locke, E.A. (2007), The motivation to work: What we know, Greenwich, CT: JAI Press.

Luna-Arocas, R. and Morley, M.J. (2018), Talent management, talent mindset competency and job performance: the mediating role of job satisfaction, Asian Journal of Social Psychology, Vol. 9, No. 1, pp. 28-51.

Luz, C. and Oliveira, L. (2018), Organizational commitment, job satisfaction and their possible influences on intent to turnover, Revista de Gestão, online, Vol. 25, No. 1, pp. 84-101. viewed at 10 April 2019, <https://doi.org/10.1108/REGE-12-2017-008>.

Mangusho, Y, Murei, R. and Nelima, E. (2015), Evaluation of Talent Management on Employees Performance in Beverage Industry: A Case of Delmonte Kenya Limited, International Journal of Humanities and Social Science, Vol. 5, No. 8, pp. 191-199.

Mary, O., Enyinna, U. and Ezinne, K. (2015), The Relationship between Talent Management and Employees Performance in Nigerian Public Sector A Study Of 
Selected Firms in Delta State, International Journal of Economics, Commerce and Management, Vol. 3, No. 5, pp. 1581-1592.

Mensah, R.D. (2015), Effects of Human Resource Management Practices on Retention of Employees in the Banking Industry in Accra, Unpublished Doctoral dissertation, Kenyatta University: Ghana.

Mensah, J.K., Bawole, J.N. and Wedchayanon, N. (2016), Unlocking the 'black box' in the talent management-employee performance relationship: Evidence from Ghana, Management Research Review, Vol. 39, No. 12, pp. 1546-1566.

Mkamburi, M. and Kamaara, M. (2017), Influence of Talent Management on Employee Performance at The United Nations: A Case of World Food Programme, The Strategic Journal of Business and Change Management, Vol. 4, No. 2, pp. 28-48.

Mwangi, M., Njuki, H., Okoth, O., Onditi, E., Kinyanjui, S., Mwirigi, F. and Wanjiru, K. (2014), Talent Management and Employee Performance: Growing Young Colleges to Well Established Organization, Developing Country Studies, Vol. 4, No. 17, pp. 111-117.

Nakhala, (2013), The Availability of Talent Management Components from Employees Perspectives: Al aqsa voice Radio Station Case Study, Faculty of Commerce: Islamic University of Gaza.

Perera, G.D.N. (2014) Impact of Employee-Organization Congruence on Job Satisfaction and Job Performance among Factory Employees in the Sri Lankan Large Apparel Sector, Proceedings of the HR Conference, Vol. 01, No.1, pp.7-19.

Perera, G.D.N. and Madagamage, G.T. (2018),Impact of Job Satisfaction and Organizational Commitment on Intention to Turnover in the Sri Lankan Hospitality Industry: Perceptions from the Generation $Y$ View Point, Sri Lankan Journal of Human Resource Management, Vol. 8, No. 1, pp. 23-35.

Perera, G.D.N. (2019), Occupational Health and Safety Practice and Job Performance: Role of Job Satisfaction, Sri Lankan Journal of Human Resource Management, Vol. 9, No. 1, pp. 1-10.

Rhoades, L (2001), Affective commitment to the organization: the contribution of perceived organizational support, Journal of Applied Psychology, Vol. 86, No. 5, pp. $825-836$.

Robbins, S.P. (2005), Organisational behaviour, Beijing: Pearson Education Company.

Sadri, A., Pirouz, H., Sharifi, S. and Farhadi, M. (2015), Studying the Impact of Talent Management on Performance of Staffs, International Academic Journal of Economics, online, Vol. 2, No. 11, pp. 50-59, viewed 29 February 2019, $<$ http://www.iaiest.com>.

Shodhganga, (2012), Job Satisfaction, Online, viewed at 01 April 2019 <www.shodhganga.inflibnet.ac.in//10603/2009/12/12_chapter2oiv.pdf.>.

Sledge, S., Miles, A. and Coppage, S. (2008), What role does culture play? A look at motivation and job satisfaction among hotel workers in Brazil, International Journal of Human Resource Management, Vol. 19, No. 9, pp. 1667-1682.

Siqueira, M.M.M. (2008), Satisfação no trabalho Medidas do comportament to organizacional, Porto Alegre: Artmed, pp. 265-274.

Tash, M., Ali, E. and Ahmadzadeh, M. (2016), The Effect of Talent Management on Employee Performance in Oil Jam Petrochemical Complex: The Mediating Role of Job Satisfaction, International Journal of Economics and Finance, online, Vol. 8, No.6,pp.226-230,viewedat30March2019,<http://dx.doi.org/10.5539/ijef.v8n6p226>. 
Whitener, E.M. (2001), Do high commitment human resource practices affect employee commitment? A cross-level analysis using hierarchical liner modelling, Journal of Management, Vol. 27, No. 5, pp. 515-535. 